\title{
The efficiency of the systematic horizontal drai-nage under irrigation conditions in low-and non-irrigated areas
}

\author{
Kharlamov 0. \\ Institute of water problems and melioration of NAAS, Vasylkivska Str., 37, Kyiv, 03022, Ukraine; e-mail: \\ Iharlamı@gmail.com
}

The purpose. To determine efficiency of regular horizontal drainage in conditions of irrigation on lowrunoff and drainless territories. Methods. Analytical, comparative-calculation, field, experimentalproduction sectors. Efficiency of drain is determined by analysis of dynamics, actual and normative depths of occurrence of groundwater table (OGW) concerning depths of underlay of sewers and absorbing wells. Results. Long irrigation has generated intense infiltration feed, ascending gradient of subsoil waters and underflooding of terrains. These processes were observed in by-channel zones, centers of sprinklers "Frigate" and on the end plates of drainless lowering. For the last 34 years waterflooding of terrains was observed in excessively wet seasons 5 times. On low-runoff and drainless terrains of irrigated lands regular shut horizontal drainage of self-flowing type due to continuous operation of deep sewers ensured essential heightening of their general drainity, reliable protection from damage effect of waters and decrease of load by field absorbing wells. Deep underlay of sewers has created conditions for formation of powerful zone of aerification and automorphic regime of pedogenesis. In wet seasons they observed formation of nucleation sites for of underflooding on the end plates of drainless lowering, in places of connection of sprinklers to hydranths and in by-channel zone despite of availability of drain. Conclusions. Regular shut horizontal drainage with deep underlay of collection network will ensure protection of low-runoff and drainless terrains from underflooding and decrease of specific extent of field absorbing wells. On the lowered landforms there is a necessity of intensification of water removal, transfer of surface runoff in underground, arrangement of additional drain and water absorbers from volume filters.

Key words: irrigation, water flooding, level of soil waters, system of drainage.

https://doi.org/10.31073/agrovisnyk201901-12

Questioning. Long-term irrigation of agricultural land in poorly drained territories leads to a critical rise in WGL and the development of degradation processes such as underflooding, flooding and salinization of soils [1-4]. Engineering drainage refers to radical means of protecting the territories from harmful effects of water $[1,3,5,6]$. The most common type is the horizontal type of drainage. The study of its efficiency in the irrigated area was conducted by V.T. Asatryan, O.A. Babitskaya, V.V. Kolesnikov, SM Kalenyuk, VV Morozov, D.P. Savchuk, V.M. Stavitsky, VM Timokhin, B.O. Tupitsyn, Yu.O. Chirva et al. [1-3,5-8].

In the irrigation systems of southern Ukraine in the conditions of low-and non-irrigated areas, developed network of irrigation canals and irrigation with wide-haul sprinkler technology, the application of the system of closed horizontal drainage with deep laying of collectors and self-inflating drainage was found. At the present stage, the effectiveness of the operation of such drainage is not sufficiently studied, and the results of its research become relevant and of scientific and practical interest in connection with the exhaustion of the normative lifetime (30 years) and the prospect of regeneration and development of irrigation in the region [9].

The purpose of the research is to establish the effectiveness of closed systematic horizontal drainage under irrigation conditions, of low-and non-irrigated areas, deep laying of collectors and selfinflating drainage. 
Research methodology. For research, the research and production area of irrigation and drainage (RDA) was selected, which is located of low-and non-irrigated areas of the Kakhovka irrigated array (Fig. 1).

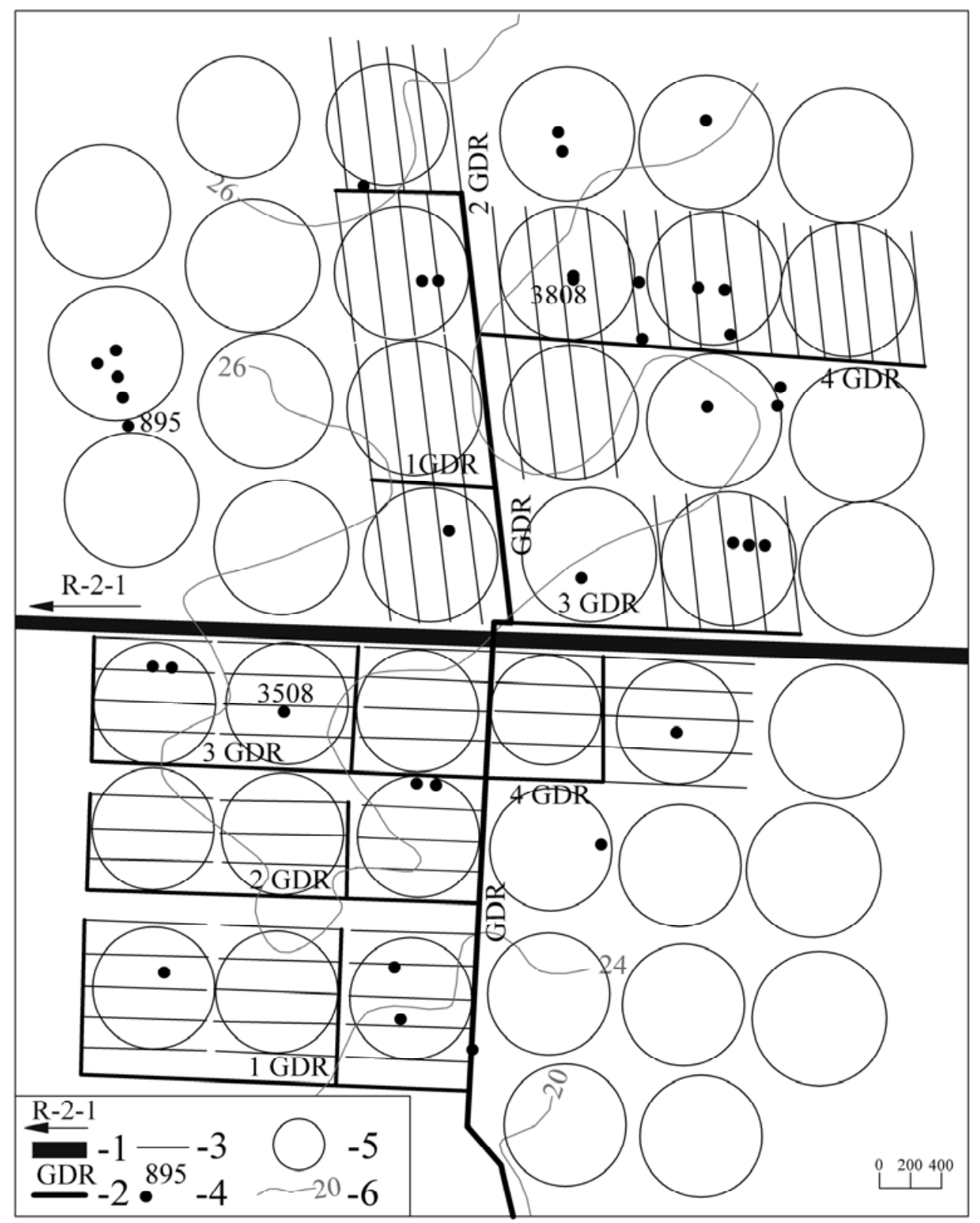

Fig. 1. Irrigation scheme and drainage on the research and production area:

1 - irrigation channel; 2 - closed collectors; 2 - closed drains; 4 - observing wells; 5 - irrigation area of SM "Fregat"; 6 - horizontal and absolute markings.

At the site, the control wells of the regional hydrogeological-reclamation batch with a long-term observation period for WGL were selected, analyzed the design and operational characteristics of irrigation and drainage systems, atmospheric drops, depths of WGL and drainage runoff, space images of flooding and irrigation of lands, compared actual and critical indicators of WGL relative to the depths of drainage and collectors [6,10]. According to [6], the critical depth in the region is $2 \mathrm{~m}$. Maintenance of such depths in conditions of irrigation favorable aqueous-salt regime of soils of aeration zone is formed, there is no accumulation of salts, there is a desalting effect of irrigation and precipitation in the upper meter layer [2]. 
According to the natural and water management conditions, the site belongs to a typical area for irrigated agriculture. The relief of the territory is flat, with a slight overall slope to the south (predominantly $0,001-0,002$ ). The area of non-irrigated lowering on the site is 322 hectares (about $18 \%$ of its total area).

The irrigation system on the site was put into operation in 1974, drainage - 1989. The design and construction of the systems was carried out in the light of the latest achievements of science and technology and best practices: the irrigation canals are equipped with anti-filtering lining, the network is represented by closed pipelines, and a technique of watering - a wide-reaching sprinkling technique with high-quality rain intensity (SM "Fregat").

The drainage system is characterized by compactness, closed pipes, self-inflating drainage, the largest area in the irrigated area - 1840 hectares. The distance between the drains is $200 \mathrm{~m}(50 \mathrm{~m} / \mathrm{ha})$, the drainage depth is $2,8-3,0 \mathrm{~m}$, the collectors are 4,9-5,3 $\mathrm{m}$. The drain diameter is $0,1 \mathrm{~m}$, the collectors are 0,2-0,6 m, slope $-0,0015$ and 0,0005 respectively.

Research results. Prolonged irrigation on the site proved to be a powerful technogenic factor, which resulted in the formation of infiltration recharge of groundwater with an intensity up to 75-120 $\mathrm{mm} / \mathrm{year}$ and the rise of WGL at a speed of about $0,8 \mathrm{~m} / \mathrm{year}$ (control well number 895) [6,11]. Regular irrigation led to the rise of WGL from a depth of $24.8 \mathrm{~m}$ from the surface of the ground to 2-3 $\mathrm{m}$ [12]. As a result, there were areas of underflooding of agricultural land on the site and in the adjoining areas. Mostly affected by near the channel zones, the central parts of the fields with the SM "Fregat" and the bottom of the non-irrigated areas (control wells number 3508, № 3808).

According to the analysis of cosmic photographs of 1984-2018, it was found that excessive damp periods of flooding at the bottom of the decline were observed at least 5 times. Their largest area was recorded in winter 1998 [4].

The introduction of drainage into operation has led to the formation of a continuous drainage runoff. At most of the territory, the collectors were included in the work, and the field drains remain dry, that is, they did not have runoff. At the side collectors the drain reached 2-4 l/s, on the main collector up to $10-20 \mathrm{l} / \mathrm{s}$. At the section of drainage on 10 positions of SM "Fregat" of 20 was formed domes of groundwater.

The work of drainage provided a steady reduction of WGL, the elimination of underflooding and stabilization of the hydrogeological and reclamation situation (Fig. 2).

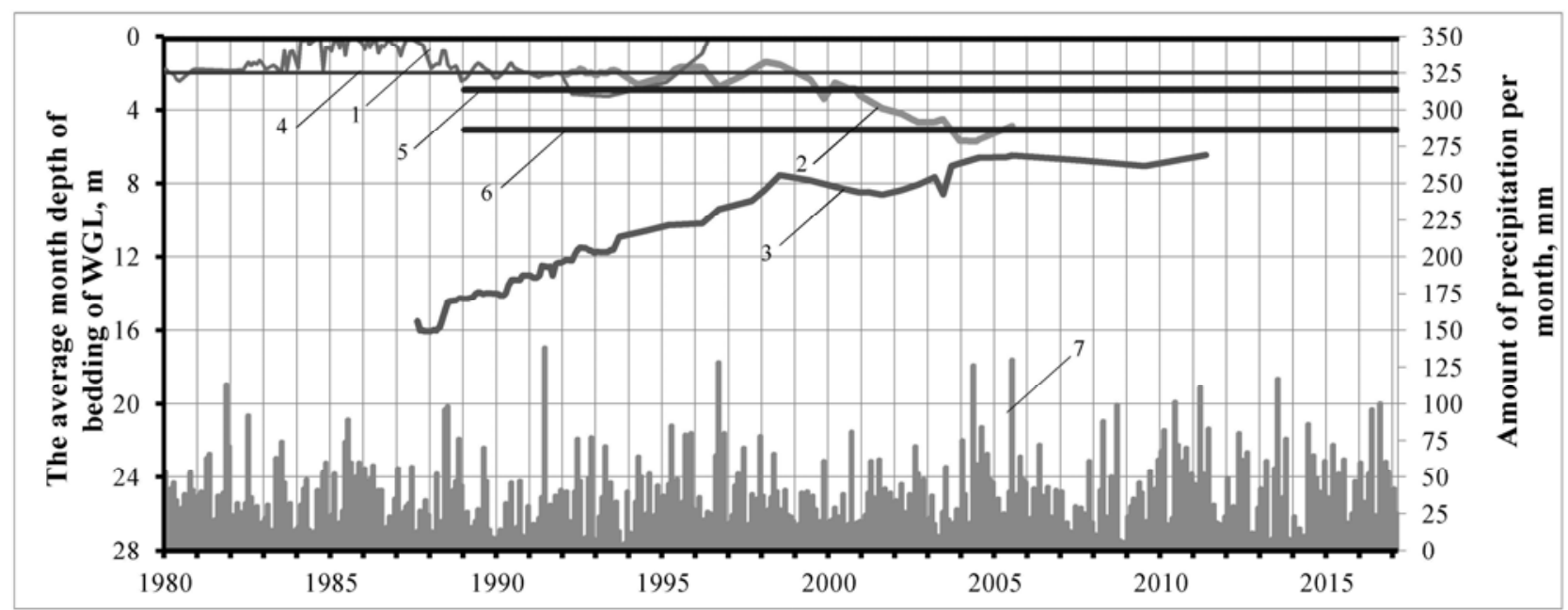

Fig. 2. Graph of vacillation of the depths of bedding of WGL in conditions of irrigation and drainage: 1 - well number 3508 in the near-canal zone; 2 - well number 3808 in the center of DM "Fregat"; 3 - well number 885 in conditions of irrigation without drainage; 4 - critical depth; 5 - line of depth laying the drain; 6 - line of depth of laying of collectors; 7 - precipitation over a month (meteorological station Askania-Nova). 
The work of deep-laying collectors has created conditions for the formation of a powerful aeration zone and an automorphic soil formation regime. Short-term restoration of underflooding was recorded only in periods with anomalous amount of precipitation.

The results of studies have shown that in order to increase the efficiency of the closed horizontal drainage, it is necessary to carry out work on the arrangement over the drains, which are located on the the bottom of the non-irrigated areas and in the centers of SM "Fregat", absorbers of the surface runoff. When designing new systems, it is necessary to take into account the improvement of drainage schemes and drafts in order to significantly reduce the specific length of field drains and increase the length of the filtering collectors, the use of perforated drainage pipes of large diameter and slim protectives and filters materials [13].

\section{Conclusion}

Systematic closed horizontal drainage with deep laying of the collector network under irrigation conditions provides effective protection of low-and non-irrigated areas from underflooding due to the continuous operation of collectors with a reduced specific length of field drains. On lowered landforms, there is a need to intensify drainage, transfer surface runoff to the underground one, arrangements of additional drainage and water absorbers from volumetric filters.

\section{References}

1. Bygai N.G., Vinogradov S.G., Vnychkov V.V. et al. (1986). Drenazhnue sistemu v zone orosheniia. [Drainage systems in the irrigation zone]. Kyiv: Urozhay. [in Russian].

2. Kolesnykov V. V. (1998) Gorizontalnyiy drenazh pochv na yuge Ukrainyi [Horizontal drainage of soils in the south of Ukraine.]. Kherson: Ailant. [in Russian].

3. Liskonov A.T., Bredihin N.N., Savchuk D.P. (1992) Zakryityiy drenazh pri oroshenii. [Closed drainage with irrigation]. Krasnoyarsk: Izd-vo Krasnoyarskogo un-ta. [in Russian].

4. Romashchenko M.I., Savchyk D.P. (1998). Pidtoplennia Pivdnia Ukrainu: prichinu ta zapobizhni zakhodu. [Flooding of the South of Ukraine: Causes and Precautionary measures]. Vodne gospodarstvo Ukrainu, 5-6, 6-12. [in Ukraine].

5. N.G. Pivovar, N.G. Bugay, V.L. Fridrihson et al. (2000) Drenazh s voloknistimi filtrami dlya zaschityi territoriy ot podtopleniya. [Drainage with fibrous filters to protect the territories from flooding]. Kyiv: Institut gidromehaniki NAN Ukrainu. [in Russian].

6. Oleunik A.la. et al. (1986). Metodicheskie rekomendacii po raschetam zashchitu territorii ot podtopleniia $v$ zone orosheniia. [Methodical recommendations on calculations of protection of territories from flooding in the irrigation zone]. Kyiv: Minvodhoz USSR, Instityt Gidromehaniki AN USSR. Ukrgiprovodkhoz. [in Russian].

7. Demchenko O. Efektivnist sistem samoplivnogo zakritogo gorizontalnogo drenazhu $v$ zoni zroshuvanogo zemlerobstva. [The efficiency of systems closed horizontal drainage of self-inflating type in irrigated agriculture]. Vodne gospodarstvo Ukrainu, 3, 43-49. [in Ukraine].

8. Savchuk D.P., Kuzminskiy V.V., Bonah I.V. (1992). Metodichni rekomendatsiyi dlya viznachennya drenazhnogo stoku na zroshuvanih zemlyah. [Methodical recommendations for determining drainage runoff on irrigated lands]. Kyiv: Ukrvodproekt. [in Ukraine].

9. Romaschenko M.I. (Eds). (2014). Kontseptslya vidnovlennya ta rozvitku zroshennya v pivdennomu regioni Ukrayinu. [Concept of Irrigation Recovery and Development in the Southern Region of Ukraine]. Kyiv: TsP «Komprint». [in Ukraine].

10. Savchuk D.P., Babitska O.A. Metodika viznachennya drenazhnogo stoku na zroshuvalnih sistemah. [Method of determination of drainage runoff on irrigation systems]. Melioratsiya $i$ vodne gospodarstvo, 96, 36-42. [in Ukraine].

11. Zhernov I.E., Muramcev N.N., Romashchenko M.I. (1978). Opredelenie infil'tracionnogo pitaniia po raschetam vlagoperenosa $v$ zone aeracii. [Determination of infiltration nutrition according to moisture 
transfer calculations in the aeration zone]. Melioraciia i vodnoe hoziaistvo, Kyiv: Urozhay, 44, 74-81. [in Russian].

12. Lozovitskiy P., Lisnichiy V. Vlastivist temno-kashtanovih gruntiv $v$ umovah trivalogo zroshennya dniprovskoyu vodoyu. [Property of dark chestnut soils in conditions of prolonged irrigation with Dnieper water]. Melioratsiya i vodne gospodarstvo, 3-4, 91-101. [in Ukraine].

13. Christen, E.W., Ayars, J.E. (2001) Subsurface drainage system design and management in irrigated agriculture: Best Management Practices for reducing drainage volume and salt load. 